\title{
Pengembangan E-Modul Pembelajaran Online Bola Besar Pendidikan Jasmani Olahraga dan Kesehatan di Masa Pandemi Covid-19 di SMAN 1 Garum Kabupaten Blitar
}

Nadhif Alief Nurhadi (1), Bima Tangguh Alam (2) Mohamad Fatih (3),

Siti Rofi'ah (4), Cindya Alfi (5)

1 Universitas Nahdlatul Ulama Blitar, Indonesia

2 Universitas Nahdlatul Ulama Blitar, Indonesia

3 Universitas Nahdlatul Ulama Blitar, Indonesia

${ }^{4}$ Universitas Nahdlatul Ulama Blitar, Indonesia

5 Universitas Nahdlatul Ulama Blitar, Indonesia

Email: ${ }^{1}$ nadhifalief@gmail.com, ${ }^{2}$ bima.tangguh.alam@gmail.com ${ }^{3}$ fatih.azix@gmail.com,

${ }^{4}$ sitirofiah.unublitar@gmail.com, ${ }^{5}$ cindyalfi22@gmail.com

\begin{tabular}{l}
\hline INFO ARTIKEL \\
\hline Riwayat Artikel: \\
Diterima : Tanggal \\
Direvisi : \\
Disetujui : \\
Dipublis :
\end{tabular}

Kata kunci: E-Modul,

Pembelajaran Online, Materi Bola Besar

Keywords: E-Modules, Online Learning, Big Ball Materials

\begin{tabular}{l} 
ABSTRAK \\
\hline Abstrak: Bahan ajar e-modul pembelajaran online bola besar \\
pendidikan jasmani olahraga dan kesehatan di masa pandemi covid-19 \\
sebagai sumber belajar yang efektif dan efisien dalam membantu \\
pembelajaran daring/online. Penelitian ini menggunakan model \\
pengembangan Borg and Gall melalui 10 tahapan yang sudah \\
dimodifikasi menjadi 7 tahapan. Pada tahap validasi produk dilakukan \\
2 validator, ahli media dan materi. Selain itu responden penelitian guru \\
dan peserta didik. Instrumen yang digunakan, Wawancara, Observasi, \\
Lembar Validasi Produk, dan Lembar Kuesioner responden. Hasil \\
penelitian e-modul pembelajaran online bola besar menunjukkan hasil \\
penilaian memenuhi kriteria "Valid", dan kategori penilaian "Layak" \\
dan "Sangat Layak" sehingga dapat dijadikan bahan ajar dalam \\
pembelajaran online bola besar di SMAN 1 Garum Kabupaten Blitar. \\
Abstract: Teaching materials for e-module online learning, physical \\
education, sports and health during the COVID-19 pandemic as an \\
effective and efficient learning resource in assisting online learning. \\
This study uses the Borg and Gall development model through 10 \\
stages which have been modified into 7 stages. At the product \\
validation stage, 2 validators were carried out, media and material \\
experts. In addition, the research respondents were teachers and \\
students. The instruments used were interviews, observations, product \\
validation sheets, and respondents' questionnaire sheets. The results of \\
the research on the big ball online learning e-module show that the \\
results of the assessment meet the "Valid" criteria, and the "Decent" \\
and "Very Eligible" assessment categories so that they can be used as \\
teaching materials in online learning big balls at SMAN 1 Garum, Blitar \\
Regency.
\end{tabular}

PENDAHULUAN

Pembaharuan dalam proses pembelajaran perlu dilakukan guna menyesuaikan ketepatan dalam melaksanakan proses pembelajaran. Hal ini sesuai pendapat Pujilestari dalam Jauhari et al., (2020) menyatakan pendidikan dalam pemerintahan Indonesia salah satunya Kementrian Pendidikan dan Kebudayaan mengambil keputusan untuk pelaksanaan proses pembelajaran dilakukan dari rumah.

Dampak dari wabah pandemi covid-19 sangat signifikan dan merubah semua kegiatan dalam semua bidang, salah satunya bidang pendidikan di SMAN 1 Garum Kabupaten Blitar yaitu pendidikan jasmani olahraga, dan kesehatan memiliki beberapa permasalahan umum, salah satu guru pendidikan jasmani kelas X di SMA Negeri 1 Garum Blitar menyebutkan, bahwa "pembelajaran online materi bola besar pada saat daring/online yang ada di SMAN 1 Garum memiliki permasalahan, diantaranya sebagai berikut; 1) kurangnya pembelajaran gerak pada materi bola besar pada saat daring/online, salah satunya proses pembelajaran pendidikan jasmani olahraga dan kesehatan yang dilakukan dengan metode ceramah dan hanya dipahami oleh sebagian peserta didik yang mengikuti pembelajaran tatap muka, sehingga proses pembelajaran menjadi kurang optimal. 2) kurang optimalnya pembelajaran 
materi bola besar yang digunakan, dengan beberapa keterbatasan yaitu; keterbatasan sarana prasarana, dan sumber belajar yang kurang memenuhi karakteristik peserta didik pada pembelajaran bola besar pada saat daring/online".

Berikutnya berdasarkan temuan pembelajaran di SMAN 1 Garum Kabupaten Blitar proses pembelajaran yang dilakukan dengan menggunakan dua sistem alternatif dalam pembelajaran daring/online, meliputi sebagai berikut; 1) alternatif pertama menggunakan sistem pembelajaran daring/online, dan 2) alternatif kedua menggunakan sistem ganjil genap dalam proses pembelajaran pendidikan jasmani.

Salah satu cara yang dapat menunjang proses pembelajaran daring/online dengan menyusun bahan ajar sebagai sumber tambahan dalam pembelajaran. Hal ini sesuai dengan pendapat (Kusumam et al., 2016) pengembangan bahan ajar disusun untuk mendukung perkembangan peserta didik dalam keseimbangan antara kebutuhan jasmani dan rohani. Alat bantu belajar merupakan unsur dinamis dalam membantu proses pembelajaran.

Sesuai dengan hasil temuan dilapangan diatas solusi yang ditawarkan peneliti mengenai pembelajaran online bola besar dengan menggunakan alternatif pilihan jawaban yaitu dengan pembuatan Bahan Ajar E-Modul pembelajaran Bola Besar meliputi bola voly, sepak bola, dan bola basket. Hal ini sesuai dengan pendapat (Qomara, Dwi, 2019) materi pembelajaran bola besar merupakan materi pembelajaran yang ada di penjasorkes, sesuai dengan hasil temuan dilapangan pembelajaran penjasorkes pada materi bola besar terdapat beberapa permasalahan, selain itu pembelajaran penjasorkes merupakan pembelajaran yang memfokuskan ketepatan gerak sehingga pentingnya pengembangan bahan ajar online yang sesuai pada masa pandemi covid-19 sangat dibutuhkan dalam menunjang pembelajaran daring/online.

Pengembangan strategi pembelajaran daring/online yaitu dengan pembuatan bahan ajar modul online sebagai penunjang keaktifan peserta didik dalam proses pembelajaran daring/online berlangsung. Hal ini sesuai dengan pendapat (Purwaningtyas \& Hariyadi, 2017) modul elektronik merupakan bahan ajar yang sesuai dengan karakteristik peserta didik dalam kesatuan utuh, yang tersusun secara sitematis, efektif, dan efisien agar pebelajar lebih mandiri dan aktif belajar tanpa bimbingan dari pendidik.

Bedasarkan penelitian diatas dapat dikatakan bahwa inovasi pengembangan untuk meningkatkan kreativitas pembelajaran, dibutuhkan pembelajaran yang aktif dengan mengembangkan modul online/elektronik. Modul online/E-Modul merupakan bahan ajar yang tersusun secara sistematis sesuai dengan karakteristik materi ajar yang bertujuan agar pebelajar lebih aktif dan mandiri dengan kecepatan dan kemampuan belajarnya.

\section{Model Pengembangan}

\section{METODE}

Penelitian ini pengembangan E-Modul pembelajaran Bola Besar dengan menggunakan model pengembangan research and development $(R \& D)$. (Novitasari, 2019) research and development (R\&D) merupakan model penelitian dengan menghasilkan sesuatu yang dapat diuji kelayakan dari produk yang dibuat. Selain kelayakan produk peneliti juga menguji kevalidan produk E-Modul.

Model research and development (R\&D) yang digunakan peneliti dalam mengembangkan produk yaitu menggunakan model Borg and Gall dengan prosedur pengembangan 7 tahapan pengembangan produk.

Alasan peneliti menggunakan 7 tahapan sesuai dengan pendapat (Novitasari, 2019) penelitian pengembangan ini mengadaptasi dari beberapa penelitian terdahulu maka dari itu jika produk yang dihasilkan dalam penelitian dan pengembangan ini sudah divalidasi oleh ahli, maka produk sudah dapat dinyatakan layak, jika produk sudah tercapai sehingga produk tersebut sudah dapat diproduksi.

Prosedur pengembangan E-Modul Pembelajaran online bola besar PJOK di SMAN 1 Garum Kabupaten Blitar menggunakan Borg and Gall dengan 7 tahapan sebagai berikut: 1) analisis awal, analisis (Potensi dan Masalah) \&, 2) perencanaan biaya 3) Desain produk, (pemilihan materi dan merancang produk awal), dan 4) uji validasi ahli, 5) revisi produk awal, 6) uji coba produk, 7) revisi produk.

\section{1) Potensi dan Masalah}

Tahap pengambilan data pengembangan ini dibagi menjadi beberapa tahapan yaitu: 1) analisis awal, 2) analisis kebutuhan dan 3) perencanaan biaya. Penjelasan tahap pengambilan data sebagai berikut: 


\section{a) Analisis awal}

Proses tahap awal peneliti menentukan objek dan subjek sebelum melakukan penelitian pengembangan $e$-modul dengan melakukan analisis awal pada objek di SMAN I Garum Blitar. Sumber yang didapat dalam pengembangan E-modul dari sumber yang relevan, internet, buku dan jurnal, yang akan memudahkan peneliti dalam proses pembuatan E-modul pembelajaran online bola besar PJOK dimasa pandemi covid-19.

b) Analisis Kebutuhan

Pada tahap selanjutnya analisis kebutuhan digunakan untuk menemukan solusi permasalahan-permasalahan yang terjadi di SMAN 1 Garum Blitar. Solusi pembelajaran

\section{2) Perencanaan Biaya} yaitu dengan mengembangkan E-Modul Pembelajaran online Bola Besar.

Perencanaan biaya pembuatan produk e-modul hanya bersifat sementara, peneliti menyesuaikan kondisi dan analisis kebutuhan penelitian pengembangan.

\section{3) Perencanaan/Design}

Tahap perencanaan/design produk pengembangan modul dibagi menjadi beberapa tahapan yaitu sebagai berikut:

\section{a) Tahap Pemilihan Materi}

Pemilihan materi modul melalui sumber yang didapat dalam pengembangan $E$ - modul dari sumber yang relevan, internet, buku dan jurnal, yang akan memudahkan peneliti dalam proses pembuatan E-modul pembelajaran online bola besar PJOK dimasa pandemi covid-19 SMAN 1 Garum Blitar.

\section{b) Merancang Produk Awal}

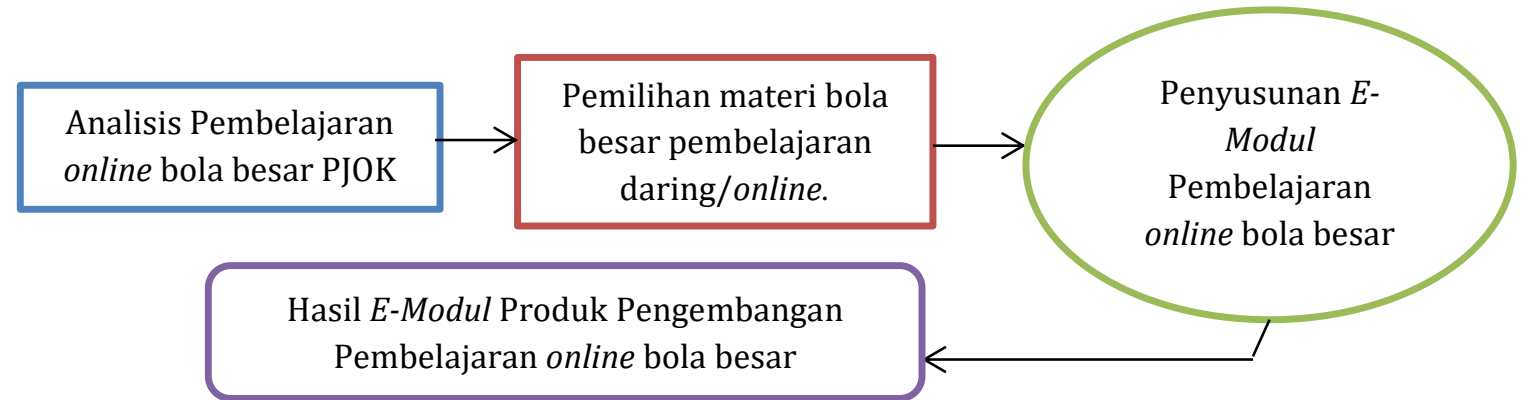

Gambar 1. Bagan Merancang Produk Awal

\section{4) Validasi Ahli}

Validasi ahli merupakan suatu langkah/prosedur dalam menilai draft produk, media pembelajaran berbentuk E-modul pada mata pembelajaran PJOK dimasa pandemi covid-19. Ada dua tahapan dalam validasi desain diantaranya sebagai berikut;

\section{a. Uji ahli media/modul online}

Uji ahli media dimaksud untuk mengetahui standart dalam pembuatan E-modul pembelajaran online bola besar PJOK dimasa pandemi covid-19, dalam mengetahui kelayakan E-modul menjadi penentu dalam strandart uji media. Uji ahli media dilakukan oleh satu orang yang ahli dalam bidang tersebut.

\section{b. Uji ahli materi}

Uji ahli materi bertujuan untuk mengetahui/menguji kelayakan materi bola besar, pembelajaran online dan kesesuaian E-modul dalam pembelajaran PJOK dimasa pandemi covid-19. Uji ahli media dilakukan oleh dosen yang mengampu pembelajaran PJOK dan pendidik di SMAN 1 Garum blitar.

\section{5) Revisi Produk Awal}

Revisi Produk Awal ini dilakukan setelah adanya validasi oleh ahli materi, media dan bahasa yang dapat diketahui kelemahan dari $e$-modul pembelajaran. Jika hasil revisi sangat besar, maka revisi tahap kedua perlu dilakukan, dan untuk revisi memiliki dampak kecil maka tidak perlu melakukan revisi, langsung dipakai dalam uji coba lapangan.

\section{6) Uji Coba Produk Skala Kecil}

Tahap uji coba skala kecil produk dilakukan guna untuk memberikan penilaian produk awal yang sudah dikembangkan, apakah produk E-modul dapat digunakan dalam bahan ajar dengan baik atau tidak. Peneliti melakukan Uji coba skala kecil di SMAN 1 Garum, dengan jumlah uji skala kecil meliputi; 1 pendidik PJOK, dan 10 peserta didik. Oleh karena itu dilakukannya uji coba produk awal ini diharapkan dapat menghasilkan produk E-modul yang baik dari segi isi materi 
dan pendekatan dalam pembelajaran serta efektif dan efisien dalam penunjang pembelajaran daring/online.

7) Revisi Produk

Tahap ini merupakan tahap yang menyesuaikan apakah uji coba produk bahan ajar berupa $e$ modul pembelajaran online materi bola besar sudah sesuai dengan kriteria kelayakan atau masih perlu perbaikan. Apabila produk belum sempurna masih ada revisi sedikit maka dapat dijadikan bahan perbaikan guna penyempurnaan bahan ajar yang akan menghasilkan produk yang siap digunakan untuk sekolah, tetapi apabila peserta didik menilai bahwa e-modul pembelajaran tersebut layak dan menarik, maka produk sudah selesai, sehingga dapat menghasilkan produk akhir tanpa revisi produk.

8) Uji Coba Produk Skala Besar

Tahap uji coba skala besar produk dilakukan guna untuk memberikan penilaian produk akhir yang sudah dikembangkan peneliti. Tahap uji coba produk skala besar dilakukan di SMAN 1 Garum, dengan jumlah uji coba yang dilakukan meliputi 30 peserta didik kelas X di SMAN 1 Garum Blitar. Pada tahap uji coba produk skala besar ini diharapkan dapat menghasilkan produk E-modul yang baik dari segi isi materi dan pendekatan dalam pembelajaran serta efektif dan efisien dalam penunjang pembelajaran daring/online yang dapat dikembangkan di SMAN 1 Garum Blitar. Sehingga produk dapat dikatakan layak dan digunakan dalam menunjang proses pembelajaran online bola besar.

\section{Subjek Penelitian}

Subjek dalam penelitian ini adalah 1) Validator Materi PJOK, 2) 1 Validator Media, Guru PJOK dan peserta didik kelas X dengan jumlah uji skala kecil 10 peserta didik dan uji skala besar menggunakan 30 peserta didik di SMAN 1 Garum Blitar. Subjek yang dipilih untuk menilai produk pengembangan E-modul Pembelajaran online Bola besar PJOK.

\section{Instrumen Pengumpulan Data}

Instrumen yang peneliti gunakan dalam penelitian research and development ( $R \& D)$, meliputi 1) Wawancara, 2) Observasi, 3) Lembar Validasi Produk, dan 4) Lembar Kuesioner responden. Pengujian instrumen ini dengan menggunakan uji validitas dengan membandingkan isi teori yang ada didalam instrument.

\section{Teknik Analisis Data}

Teknik analisis data penelitian pengembangan ini digunakan untuk memberikan penilaian dengan menguraikan kritik dan saran yang ada di instrumen angket yang diberikan kepada uji produk meliputi, respon guru PJOK dan responden peserta didik. Data yang didapat dari angket kuesioner berupa data kualitatif dan kuantitatif menggunakan skala likert dengan kriteria 1-5.

Analisis perhitungan dengan menggunakan presentase skor dari indikator-indikator jawaban dari pertanyaan instrumen.

Rumus presentasi skor untuk menghasilkan presentase skor sebagai berikut:

$$
P=\frac{f}{N} \times 100 \%
$$

$$
\begin{array}{lll}
\text { Keterangan : } & \mathrm{P} & =\text { Skor Penilaian } \\
\mathrm{f} & =\text { Frekuensi yang dicari } \\
\mathrm{N} & =\text { Skor Maksimal. }
\end{array}
$$

Setelah mencari skor penilaian dengan menggunakan skala likert, kemudian peneliti mencari rata-rata penilaian untuk mengetahui kualitas dan kelayakan produk yang dihasilkan bedasarkan pendapat responden.

Tabel 3.12 Kriteria Persentase Kelayakan untuk Responden E-Modul

\begin{tabular}{|c|c|c|}
\hline No & Skor rata-rata (\%) & Kriteria \\
\hline 1. & $0-49,99$ & Sangat Kurang layak/sangat kurang menarik \\
\hline 2. & $50,00-59,99$ & Kurang Layak/kurang menarik/kurang baik \\
\hline 3. & $60,00-59,99$ & Cukup Layak/cukup menarik/cukup baik \\
\hline 4. & $60,00-79,99$ & Layak/menarik/baik \\
\hline 5. & $80,00-100$ & Sangat Layak/sangat menarik/sangat baik \\
\hline
\end{tabular}

Sumber : (Novitasari, 2019) 


\section{HASIL DAN PEMBAHASAN}

Pelaksanaan penelitian dan pengembangan produk meliputi beberapa tahapan diantaranya uji ahli media, uji ahli materi dan uji skala kecil produk dan uji skala besar produk untuk menentukan kelayakan dari produk E-Modul pembelajaran online bola besar. Adapun hasil analisa yang didapat sebagai berikut:

\section{Validasi Media}

\section{Hasil}

Pada hasil uji validasi ahli media sudah dinyatakan valid oleh ahli media aitu oleh Peni Nohantiya, M.Pd, selain itu peneliti menyerahkan E-Modul Bola Besar PJOK beserta angket penilaian produk kepada dosen ahli media pada hari Kamis, tanggal 29 April 2021 di kampus UNU Blitar. Media yang dikembangkan memiliki saran yang harus dilakukan perbaikan diantaranya sebagai berikut: 1) Judul sampul E-Modul lebih di eye catching pada materi inti (Sepak Bola, Bola Volly, dan Bola Basket) dengan ukuran diperbesar, 2) Gambar E-Modul sebaiknya lebih proposional (bisa dibesarkan), 3) Gambar disesuaikan dengan keterangan gambar, 4) Tulisan pada gambar Font lebih dikecilkan dengan UK 10 (tmsr), 5) Tampilkan barcode dengan ukuran yang lebih kecil dari gambar, jangan hanya barcode yang ditampilkan. (lebih utamakan gambar), 6) Perhatikan margin dalam penulisan dengan mempertimangkan saat penjilidan, 7) Keterangan judul BAB lebih jelas, dengan menambahkan angka, 8) Tambahkan evaluasi pembelajaran, yang bertujuan untuk mengevaluasi apakah peserta didik dapat memahami pembelajaran yang ada di e-modul dengan mengerjakan soal evaluasi, 9) Tambahkan kunci jawaban.

Hasil diatas dapat disimpulkan rata-rata skor persentase penilaian adalah $86 \%$ dengan kategori "Sangat Valid" dan "dapat digunakan Tanpa Revisi" dari jumlah skor total angket 121 dan skor maksimal angket 140 .

Penilaian ahli media dengan menggunakan skala penilaian yaitu 01,00 - 50,00 = tidak setuju, $50.1-70,00=$ kurang valid, 70,01 - 85,00 = cukup valid, 85,01 $-100=$ Sangat Valid.

Tabel 1. Hasil Uji Validasi Ahli Media

\begin{tabular}{|c|c|c|c|c|c|c|}
\hline No & Indikator Penilaian & $T_{s e}$ & $T_{s h}$ & Skor \% & Kategori & Keputusan Uji \\
\hline 1. & Ukuran E-Modul & 8 & 10 & $80 \%$ & Cukup Valid & Dapat digunakan dengan revisi kecil \\
\hline 2. & Tata letak E-Modul & 16 & 20 & $80 \%$ & Cukup Valid & Tidak boleh digunakan \\
\hline 3. & Tipo Cover E-Modul & 29 & 35 & $83 \%$ & Cukup Valid & Dapat digunakan dengan revisi kecil \\
\hline 4. & $\begin{array}{l}\text { Tata letak isi } E- \\
\text { Modul }\end{array}$ & 38 & 45 & $84 \%$ & Cukup Valid & Dapat digunakan dengan revisi kecil \\
\hline 5. & Tipo Isi E-Modul & 15 & 15 & $100 \%$ & Sangat Valid & Dapat digunakan Tanpa Revisi \\
\hline 6. & Bahasa E-Modul & 13 & 15 & $87 \%$ & Sangat Valid & Dapat digunakan Tanpa Revisi \\
\hline \multicolumn{3}{|c|}{ Jumlah Total } & \multicolumn{3}{|l|}{121} & \\
\hline \multicolumn{3}{|c|}{ Skor Maksimal } & \multicolumn{3}{|l|}{140} & \\
\hline \multicolumn{3}{|c|}{ Persentase } & \multicolumn{3}{|l|}{$86 \%$} & \\
\hline \multicolumn{3}{|c|}{ Kriteria uji kevalidan } & \multicolumn{3}{|c|}{ Sangat V } & Dapat digunakan Tanpa Revisi \\
\hline
\end{tabular}

\section{Validasi Materi}

Pada hasil uji validasi ahli media sudah dinyatakan valid oleh ahli media yaitu oleh Bima Tangguh Alam, M.Pd, selain itu peneliti menyerahkan E-Modul Bola Besar PJOK beserta angket penilaian produk kepada dosen ahli media pada hari Kamis, tanggal 21 April 2021 di kampus UNU Blitar. Media yang dikembangkan memiliki saran yang harus dilakukan perbaikan diantaranya sebagai berikut: 1) Perlu menambahkan alat yang dibutuhkan seperti saran prasarana apa yang digunakan dan dijelaskan pada bagian awal BAB, 2) Perlu menambahkan SKL (Standart Kompetensi Lulusan), dari pembelajaran bola besar meliputi: Sepak Bola, Bola Basket, dan Bola Volly.

Hasil diatas dapat disimpulkan rata-rata skor persentase penilaian adalah $85 \%$ dengan kategori "Cukup Valid" dan "dapat digunakan dengan revisi kecil" dari jumlah skor total angket 51 dan skor maksimal angket 60.

Penilaian ahli media dengan menggunakan skala penilaian yaitu $01,00-50,00=$ tidak setuju, $50.1-70,00=$ kurang valid, 70,01 - 85,00 = cukup valid, 85,01 $-100=$ Sangat Valid.

Tabel 2. Hasil Uji Validasi Ahli Materi 


\begin{tabular}{|r|l|c|c|c|c|l|}
\hline No & Indikator Penilaian & $\boldsymbol{T}_{\boldsymbol{s e}}$ & $\boldsymbol{T}_{\boldsymbol{s h}}$ & Skor \% & Kategori & \multicolumn{1}{|c|}{ Keputusan Uji } \\
\hline 1. & Aspek Self Instruction & 27 & 30 & $90 \%$ & Sangat Valid & Dapat digunakan tanpa revisi \\
\hline 2. & Aspek Self Contained & 9 & 10 & $90 \%$ & Sangat Valid & Dapat digunakan tanpa revisi \\
\hline 3. & Aspek Self Stand Alone & 6 & 10 & $60 \%$ & Kurang Valid & Dapat digunakan dengan revisi besar \\
\hline 4. & Aspek Adaptive & 4 & 5 & $80 \%$ & Sangat Valid & Dapat digunakan dengan revisi kecil \\
\hline 5. & Aspek User Friendly & 5 & 5 & $100 \%$ & Sangat Valid & Dapat digunakan tanpa revisi \\
\hline Jumlah Total & $\mathbf{5 1}$ & & \\
\hline Skor Maksimal & $\mathbf{6 0}$ & $\begin{array}{c}\text { Dapat digunakan dengan revisi } \\
\text { kecil }\end{array}$ \\
\hline Persentase & $\mathbf{8 5 \%}$ & \\
\hline Kriteria uji kevalidan & \multicolumn{7}{|l}{ Cukup Valid } & & \\
\hline
\end{tabular}

\section{Uji Skala Kecil}

Data hasil uji coba produk skala kecil ini yang bertujuan untuk menguji tahap awal kelayakan E-Modul Bola Besar PJOK, dengan mengambil responden 1 guru PJOK kelas X, dan 10 peserta didik kelas X. alasan peneliti mengambil sampel uji coba skala kecil sesuai dengan model pengembangan Borg and Gall dengan sampel uji coba terbatas 10-30 orang. Jenis sampel yang digunakan dalam uji skala kecil ini menggunakan Quota Sampling, yaitu dengan jumlah sampel yang sudah ditentukan oleh peneliti. Uji skala kecil dilakukan pada tanggal 6 Mei 2021 yang bertempat diruang kelas X MIPA 1 SMAN 1 Garum Kabupaten Blitar.

Tabel 3. Data Hasil Uji Coba Produk Skala Kecil Guru PJOK

\begin{tabular}{|c|c|c|c|c|c|}
\hline No & Aspek Penilaian & $\sum_{\text {Aspek }} X$ & $\begin{array}{c}\text { Skor } \\
\text { Maksimal }\end{array}$ & Skor \% & Kategori Kelayakan E-Modul \\
\hline 1. & Kelayakan E-Modul & 38 & 45 & $84 \%$ & Sangat Layak/sangat menarik/sangat baik \\
\hline 2. & Bahasa E-Modul & 14 & 15 & $93 \%$ & Sangat Layak/sangat menarik/sangat baik \\
\hline 3. & Kemanfaatan E-Modul & 16 & 20 & $80 \%$ & Sangat Layak/sangat menarik/sangat baik \\
\hline 4. & Kegrafikan E-Modul & 28 & 35 & $80 \%$ & Sangat Layak/sangat menarik/sangat baik \\
\hline \multicolumn{3}{|c|}{ Jumlah Total } & \multicolumn{3}{|l|}{96} \\
\hline \multicolumn{3}{|c|}{ Skor Maksimal } & \multicolumn{3}{|l|}{115} \\
\hline \multicolumn{3}{|c|}{ Persentase } & \multicolumn{3}{|l|}{$83,47 \%$} \\
\hline \multicolumn{3}{|c|}{ Kriteria Kelayakan E-Modul } & \multicolumn{3}{|c|}{ Sangat Layak/sangat menarik/sangat baik } \\
\hline
\end{tabular}

Sesuai hasil diatas dapat diperoleh rata-rata skor persentase hasil uji skala kecil yaitu dengan memperoleh skor 96 dengan skor maksimal 115 serta persentase kriteria keseluruhan aspek kelayakan E-Modul yang didapat adalah $83,47 \%$ dengan kategori Sangat Layak/sangat menarik/sangat baik.

Penilaian dari responden guru dan peserta didik dengan menggunakan skala penilaian yaitu 1) $0-49,99=$ Sangat Kurang layak/sangat kurang menarik, 2) 50,00-59,99 $=$ Kurang Layak/kurang menarik/kurang baik, 3) 60,00-59,99 = Cukup Layak/cukup menarik/cukup baik, 4) 60,00-79,99 = Layak/menarik/baik, 5) 80,00-100 = Sangat Layak/sangat menarik/sangat baik.

Data hasil penilaian validasi ahli materi juga disediakan dalam bentuk grafik, dengan tampilan grafik penilaian sebagai berikut:

\section{Uji Skala Kecil Kelayakan E-Modul Untuk Guru PJOK}

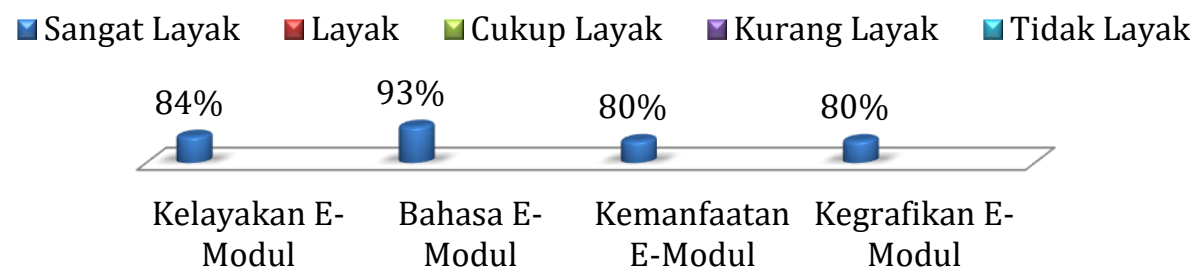


Patria Education Jurnal (PEJ) Vol 01 No.02 September 2021 berikut:

Adapun tabel penilaian kelayakan dari peserta didik, hasil dari Uji Skala Kecil Produk sebagai

Tabel 4. Data Hasil Uji Coba Produk Skala Kecil

\begin{tabular}{|c|l|c|c|c|c|}
\hline No & \multicolumn{1}{|c|}{ Aspek Penilaian } & $\begin{array}{c}\sum \boldsymbol{X} \\
\text { Aspek }\end{array}$ & $\begin{array}{c}\text { Skor } \\
\text { Maksimal }\end{array}$ & $\begin{array}{c}\text { Skor } \\
\mathbf{\%}\end{array}$ & Kategori Kelayakan E-Modul \\
\hline 1. & Kelayakan E-Modul & 275 & 350 & $\begin{array}{c}78,5 \\
\%\end{array}$ & Layak/menarik/baik \\
\hline 2. & Bahasa E-Modul & 126 & 150 & $84 \%$ & Sangat Layak/sangat menarik/sangat baik \\
\hline 3. & Kemanfaatan E-Modul & 165 & 200 & $\begin{array}{c}82,5 \\
\%\end{array}$ & Sangat Layak/sangat menarik/sangat baik \\
\hline 4. & Kegrafikan E-Modul & 279 & 350 & $80 \%$ & Sangat Layak/sangat menarik/sangat baik \\
\hline Jumlah Total & & $\mathbf{8 4 5}$ & \\
\hline Skor Maksimal & $\mathbf{1 . 1 0 1}$ \\
\hline Persentase & $\mathbf{7 7 \%}$ \\
\hline \multicolumn{2}{|l|}{ Kriteria Kelayakan E-Modul } & Layak/menarik/baik \\
\hline
\end{tabular}

Sesuai hasil diatas dapat diperoleh rata-rata skor persentase hasil uji skala kecil yaitu dengan memperoleh skor 845 dengan skor maksimal 1.101 serta persentase kriteria keseluruhan aspek kelayakan E-Modul yang didapat adalah 77\% dengan kategori "Layak/Menarik/baik".

Penilaian dari responden guru dan peserta didik dengan menggunakan skala penilaian yaitu 1) $0-49,99=$ Sangat Kurang layak/sangat kurang menarik, 2) 50,00-59,99 = Kurang Layak/kurang menarik/kurang baik, 3) 60,00-59,99 = Cukup Layak/cukup menarik/cukup baik, 4) 60,00-79,99= Layak/menarik/baik, 5) 80,00-100 = Sangat Layak/sangat menarik/sangat baik.

Data hasil penilaian validasi ahli materi juga disediakan dalam bentuk grafik, dengan tampilan grafik penilaian sebagai berikut:

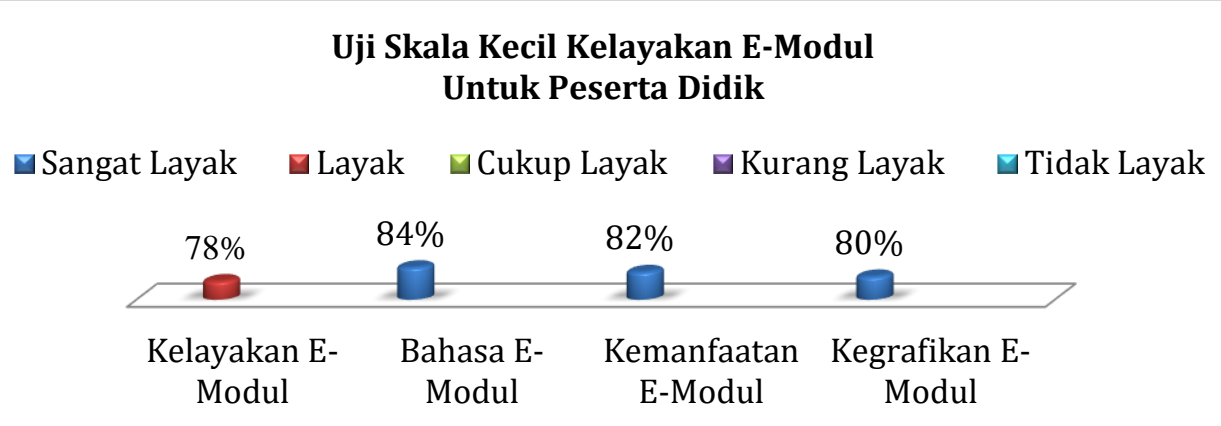

\section{Uji Coba Skala Besar}

Data hasil uji coba produk skala besar ini yang bertujuan untuk menguji kelayakan E-Modul Bola Besar PJOK agar dapat diproduksi secara massal dan dapat digunakan untuk membantu pembelajaran daring/online di SMAN 1 Garum Kabupaten Blitar, dengan mengambil responden 30 peserta didik kelas $\mathrm{X}$.

Alasan peneliti mengambil sampel uji coba skala besar sesuai dengan model pengembangan Borg and Gall dengan sampel uji coba terbatas 30-100 orang. Jenis sampel yang digunakan dalam uji skala kecil ini menggunakan Quota Sampling, yaitu dengan jumlah sampel yang sudah ditentukan oleh peneliti. Uji coba skala besar dilakukan pada tanggal 31 Mei 2021 dan 2 Juni 2021 yang bertempat diruang kelas X MIPA 1 SMAN 1 Garum Kabupaten Blitar.

Tabel 5. Hasil Uji Coba Produk Kelayakan Skala Besar Peserta Didik

\begin{tabular}{|c|l|c|c|c|c|}
\hline No & \multicolumn{1}{|c|}{ Aspek Penilaian } & $\begin{array}{c}\sum_{\text {Aspek }} \boldsymbol{X} \\
\text { Maksimal }\end{array}$ & $\begin{array}{c}\text { Skor } \\
\text { Skor } \%\end{array}$ & Kategori Kelayakan E-Modul \\
\hline 1. & Kelayakan E-Modul & 934 & 1.085 & $86 \%$ & Sangat Layak/sangat menarik/sangat baik \\
\hline 2. & Bahasa E-Modul & 414 & 450 & $92 \%$ & Sangat Layak/sangat menarik/sangat baik \\
\hline 3. & Kemanfaatan E-Modul & 553 & 600 & $92 \%$ & Sangat Layak/sangat menarik/sangat baik \\
\hline 4. & Kegrafikan E-Modul & 954 & 1.085 & $87 \%$ & Sangat Layak/sangat menarik/sangat baik \\
\hline Jumlah Total & & $\mathbf{2 . 8 5 5}$ & \\
\hline Skor Maksimal & $\mathbf{3 . 2 2 0}$ \\
\hline Persentase & $\mathbf{8 9 \%}$ \\
\hline Kriteria Kelayakan E-Modul & \multicolumn{3}{l}{ Sangat Layak/Sangat menarik/Sangat baik } \\
\hline
\end{tabular}

Sesuai hasil diatas dapat diperoleh rata-rata skor persentase hasil uji skala besar yaitu dengan 
memperoleh skor 2.855 dengan skor maksimal 3.220 serta persentase kriteria keseluruhan aspek kelayakan e-modul yang didapat adalah $89 \%$ dengan kategori "Sangat Layak/sangat menarik/sangat baik".

Penilaian dari responden guru dan peserta didik dengan menggunakan skala penilaian yaitu 1) 0-49,99 = Sangat Kurang layak/sangat kurang menarik, 2) 50,00-59,99 = Kurang Layak/kurang menarik/kurang baik, 3) 60,00-59,99 = Cukup Layak/cukup menarik/cukup baik, 4) 60,00-79,99 = Layak/menarik/baik, 5) 80,00-100 = Sangat Layak/sangat menarik/sangat baik.

Data hasil penilaian validasi ahli materi juga disediakan dalam bentuk grafik, dengan tampilan grafik penilaian sebagai berikut:

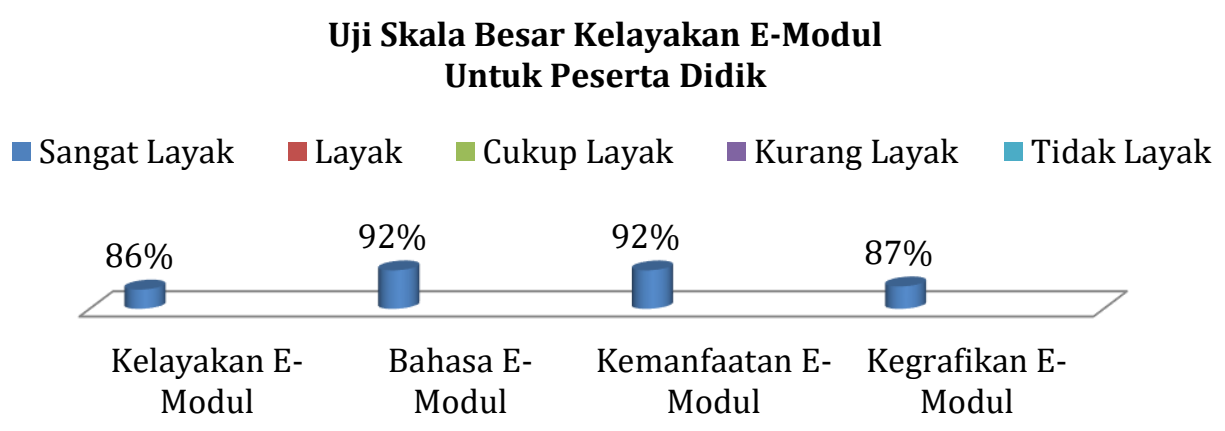

\section{Revisi Hasil Produk Pengembangan}

Data yang diperoleh dari hasil analisis pengembangan bahan ajar e-modul pembelajaran online bola besar PJOK di SMAN 1 Garum Kabupaten Blitar memenuhi kriteria valid, dan layak. Pada aspek penilaian terdapat beberapa saran dari beberapa ahli yaitu ahli media dan ahli materi serta responden penelitian meliputi guru dan peserta didik.

Hal tersebut mengacu pada data hasil uji validasi media dengan mendapat saran sebagai berikut: 1) Judul sampul E-Modul lebih di eye catching pada materi inti (Sepak Bola, Bola Volly, dan Bola Basket) dengan ukuran diperbesar, 2) Gambar E-Modul sebaiknya lebih proposional (bisa dibesarkan), 3) Gambar disesuaikan dengan keterangan gambar, 4) Tulisan pada gambar Font lebih dikecilkan dengan UK 10 (tmsr), 5) Tampilkan barcode dengan ukuran yang lebih kecil dari gambar, jangan hanya barcode yang ditampilkan. (lebih utamakan gambar), 6) Perhatikan margin dalam penulisan dengan mempertimangkan saat penjilidan, 7) Keterangan judul BAB lebih jelas, dengan menambahkan angka, 8) Tambahkan evaluasi pembelajaran, yang bertujuan untuk mengevaluasi apakah peserta didik dapat memahami pembelajaran yang ada di $e$-modul dengan mengerjakan soal evaluasi, 9) Tambahkan kunci jawaban.

Saran dari ahli materi sebagai berikut: 1) Perlu menambahkan alat yang dibutuhkan seperti saran prasarana apa yang digunakan dan dijelaskan pada bagian awal BAB, 2) Perlu menambahkan SKL (Standart Kompetensi Lulusan), dari pembelajaran bola besar meliputi: Sepak Bola, Bola Basket, dan Bola Volly.

Saran responden uji skala kecil yaitu sebagai berikut: 1) Desain cover e-modul kurang menarik, sebaiknya diperbagus lagi agar peserta didik lebih tertarik untuk membaca dan mempelajarinya.

Saran responden uji skala besar yaitu sebagai berikut: 1) Pengembangan $e$-modul pembelajaran online sudah bagus dan tepat, dan perlu adanya pengembangan lagi terkait materimateri PJOK yang lainnya, dengan menambahkan seperti materi bola kecil dan atletik.

\section{Pembahasan}

Berdasarkan hasil penelitian dan pengembangan $e$-modul pembelajaran online bola besar PJOK di SMAN 1 Garum Kabupaten Blitar diperoleh nilai kevalidan dan kelayakan bahan ajar sangat baik.

\section{Prosedur Pengembangan}

Prosedur penelitian pengembangan ini menggunakan Model Borg and Gall, dengan menyesuaikan analisis kebutuhan penelitian serta atas dasar pertimbangan dari penelitian terdahulu dengan menyatakan bahwa secara garis besar prosedur pengembangan yang seharusnya melalui 10 tahapan disederhanakan 7 tahapan yaitu, 1) Potensi dan masalah, 2) perencanaan biaya, 3) Design Produk (Pemilihan Materi dan Merancang Produk Awal), dan 4) Uji Validasi Ahli, 5) Revisi Produk, 6) 
Patria Education Jurnal (PEJ) Vol 01 No.02 September 2021

Uji Coba Produk, dan 7) Revisi Produk digunakan untuk mengatahui kevalidan produk dan kelayakan produk dimana kevalidan ditentukan oleh ahli validasi dan untuk kelayakan ditentukan oleh guru dan peserta didik.

\section{Kevalidan E-Modul Pembelajaran Online}

Validasi oleh ahli media dengan penilaian kevalidan produk, hasil penelitian pada ahli media dengan mendapat penilaian enam indikator aspek validasi media memperoleh penilaian diantaranya sebagai berikut, pada Ukuran E-Modul memperoleh jumlah skor 8 dengan skor maksimal maksimal 10 serta persentase yang diperoleh $80 \%$, kemudian Tata letak E-Modul memperoleh jumlah skor 16 dengan skor maksimal 20 serta persentase yang diperoleh $80 \% \%$, untuk Tipografi Cover E-Modul memperoleh skor 29 dengan skor maksimal 35 serta persentase yang diperoleh 83\%, untuk Tata letak isi E-Modul memperoleh skor 38 dengan skor maksimal 45 serta persentase yang diperoleh $84 \%$, untuk Tipo Isi E-Modul memperoleh skor 15 dengan skor maksimal 15 serta persentase yang diperoleh 100\%, untuk Bahasa E-Modul memperoleh skor 13 dengan skor maksimal 15 serta persentase yang diperoleh $87 \%$.

Berdasarkan penjelasan diatas dapat disimpulkan rata-rata skor persentase penilaian adalah 86\% dengan kategori "Sangat Valid" dan "dapat digunakan Tanpa Revisi" dari jumlah skor total angket 121 dan skor maksimal angket 140.

Kemudian untuk Uji Ahli Materi mendapatkan penilaian dari lima indikator aspek validasi materi memperoleh penilaian diantaranya sebagai berikut, pada aspek Self Instruction memperoleh jumlah skor 27 dengan skor maksimal maksimal 30 serta persentase yang diperoleh 90\%, kemudian Aspek Self Contained memperoleh jumlah skor 9 dengan skor maksimal 10 serta persentase yang diperoleh 90\%, untuk Aspek Self Stand Alone memperoleh skor 6 dengan skor maksimal 10 serta persentase yang diperoleh 60\%, untuk aspek Adaptive memperoleh skor 4 dengan skor maksimal 5 serta persentase yang diperoleh 80\%, untuk Aspek User Friendly memperoleh skor 5 dengan skor maksimal 5 serta persentase yang diperoleh $100 \%$.

Berdasarkan pemaparan hasil diatas dapat disimpulkan rata-rata skor persentase penilaian adalah 85\% dengan kategori "Cukup Valid" dan "dapat digunakan dengan revisi kecil” dari jumlah skor total angket 51 dan skor maksimal angket 60.

Berdasarkan hasil uji kevalidan dapat disimpulkan dari masing-masing ahli validasi media dengan kategori "Sangat Valid" dan "dapat digunakan Tanpa Revisi" dan ahli validasi materi mendapat kategori "Cukup Valid" dan "dapat digunakan dengan revisi kecil". Hal tersebut selaras dengan pendapat (Rahdiyanta, 2016) yang menyatakan bahwa e-modul dapat digunakan sendiri oleh siswa dalam melakukan pembelajaran sebagai sumber bahan ajar dengan masing-masing karakteristiknya meliputi, Self Instruction, Self Contained, Self Stand Alone, Adaptive, dan User Friendly yang dapat meningkatkan motivasi pembelajaran siswa.

\section{Kelayakan E-Modul Pembelajaran Online}

Penilaian Uji Skala Kecil dengan aspek penilaian angket yang diberikan kepada peserta didik mendapatkan beberapa penilaian diantaranya sebagai berikut, pada aspek Kelayakan E-Modul memperoleh skor 275 dengan skor maksimal 350 serta persentase yang didapat 78,5\%, kemudian untuk aspek bahasa E-Modul memperoleh skor 126 dengan skor maksimal 150 serta persentase yang didapat 84\%, untuk aspek Kemanfaatan E-Modul memperoleh skor 165 dengan skor maksimal 200 serta persentase yang didapat 82,5\%, untuk aspek Kegrafikan E-Modul memperoleh skor 279 dengan skor maksimal 350 serta persentase yang didapat $80 \%$.

Berdasarkan pemaparan hasil diatas dapat diperoleh rata-rata skor persentase hasil uji skala kecil yaitu dengan memperoleh skor 845 dengan skor maksimal 1.101 serta persentase kriteria keseluruhan aspek uji kevalidan E-Modul yang didapat adalah 77\% dengan kategori "Cukup Valid" dan "dapat digunakan dengan revisi kecil" dan kategori kelayakan e-modul mendapat kriteria "Layak/Menarik/baik".

Pada hasil penilaian produk uji skala besar dengan aspek yang diberikan kepada peserta didik mendapatkan beberapa penilaian diantaranya sebagai berikut, pada aspek Kelayakan E-Modul memperoleh skor 934 dengan skor maksimal 1.085 serta persentase yang didapat $86 \%$, kemudian untuk aspek bahasa E-Modul memperoleh skor 414 dengan skor maksimal 450 serta persentase yang didapat 92\%, untuk aspek Kemanfaatan E-Modul memperoleh skor 553 dengan skor maksimal 600 serta persentase yang didapat 92\%, untuk aspek Kegrafikan E-Modul memperoleh skor 954 dengan skor maksimal 1.085 serta persentase yang didapat $87 \%$.

Hal ini sesuai dengan kriteria kelayakan menurut (Kantun \& Budiawati, 2015) kriteria kelayakan dapat digunakan untuk guru dan peserta didik dalam menilai kelayakan $e$-modul dengan 
kriteria kelayakan E-Modul meliputi sebagai berikut; 1) Kelayakan Isi, 2) Kelayakan Kebahasaan, 3) Kelayakan Penyajian, dan 4) Kelayakan Kegrafikan.

Berdasarkan hasil diatas dapat diperoleh rata-rata skor persentase penilaian hasil uji skala kecil yaitu dengan memperoleh skor 2.855 dengan skor maksimal 3.220 serta persentase kriteria keseluruhan aspek uji kelayakan E-Modul dengan kategori Produk Uji Skala Besar memperoleh 89\% dengan kategori "Sangat Layak/sangat menarik/sangat baik".

Berdasarkan penelitian pengembangan yang telah dilaksanakan menunjukkan bahwa produk E-Modul pembelajaran online yang dikembangkan mendapat kategori penilaian "layak/Menarik/Baik" dan "Sangat Layak/Sangat Menarik/Sangat Baik" dari responden penelitian melalui tahap uji coba produk pengembangan. Hal ini dapat dikatakan bahwa pengembangan bahan ajar E-Modul dapat digunakan sebagai sumber belajar online untuk peserta didik di SMAN 1 Garum Kabupaten Blitar.

\section{SIMPULAN}

1) Penelitian ini bertujuan untuk menghasilkan produk bahan ajar E-Modul Pembelajaran Online Bola Besar Pendidikan Jasmani Olahraga, dan Kesehatan pada materi Bola Besar sebagai sumber belajar yang efektif dan efisien yang dapat digunakan dalam pembelajaran daring/online. Prosedur penelitian pengembangan ini menggunakan Model Borg and Gall, dengan menyesuaikan analisis kebutuhan penelitian serta atas dasar pertimbangan dari penelitian terdahulu dengan menyatakan bahwa secara garis besar prosedur pengembangan yang seharusnya melalui 10 tahapan disederhanakan 7 tahapan yaitu, 1) Potensi dan masalah, 2) perencanaan biaya, 3) Design Produk (Pemilihan Materi dan Merancang Produk Awal), dan 4) Uji Validasi Ahli, 5) Revisi Produk, 6) Uji Coba Produk, dan 7) Revisi Produk digunakan untuk mengatahui kevalidan produk dan kelayakan produk dimana kevalidan ditentukan oleh ahli validasi dan untuk kelayakan ditentukan oleh guru dan peserta didik.

2) Bedasarkan hasil perhitungan analisis Validasi oleh ahli media dan materi dengan 2 tahapan penilaian kevalidan dan kelayakan produk, hasil penelitian pada ahli media mencapai skor $86 \%$ serta kategori penilaian "Sangat Valid" dan "Dapat digunakan Tanpa Revisi", kemudian untuk uji ahli materi mencapai skor 85\% serta kategori penilaian "Cukup Valid" dan "Dapat digunakan dengan revisi kecil".

3) Berdasarkan penilaian kelayakan produk dapat diperoleh dengan hasil persentase skor penilaian Kelayakan dari responden peserta didik dan guru sehingga diperoleh uji skala kecil produk memperoleh 77\% dengan kategori "Layak/Menarik/baik", dan untuk penilaian produk uji skala besar produk memperoleh 89\% dengan kategori "Sangat Layak/Sangat menarik/sangat baik".

Maka dari itu dapat disimpulkan bahwa hasil pengembangan E-Modul dalam Pembelajaran Online Bola Besar Pendidikan Jasmani Olahraga, dan Kesehatan Di masa Pendemi Covid-19 di SMAN 1 Garum Kabupaten Blitar dapat dijadikan bahan ajar dalam pembelajaran bola besar dengan materi teknik dasar Sepak Bola, Bola Volly, dan Bola Basket.

\section{UCAPAN TERIMA KASIH}

Penyusunan artikel merupakan suatu bentuk pertanggungjawaban tertulis atas terselesaikannya tugas akhir, penyusunan artikel tidak dapat terlaksana tanpa adanya bantuan dan kerja sama dari dosen pembimbing khususnya di Universitas Nahdlatul Ulama Blitar serta dari pihakpihak yang mendukung penyusunan artikel ini, dan tidak lupa saya ucapkan terima kasih kepada staf dan karyawan yang ada di SMAN 1 Garum Kabupaten Blitar.

\section{DAFTAR PUSTAKA}

Akbar, Sa'dun. (2017). Instrumen Perangkat Pembelajaran, Bandung; PT. Remaja Rosakarya. Kemendibud, M. (2021). Panduan Penyelenggaraan Pembelajaran Pada Semester Genap. 2019.

Jauhari, M. N., Sambira, \& Zakiah, Z. (2020). Dampak Pandemi Covid-19 Terhapad Pelaksanaan Pembelajaran Penjas Adaptif Di Sekolah Luar Biasa. Journal STAND: Sports and Development, 1(1), 63-70.

Kantun, S., \& Budiawati, Y. S. R. (2015). Analisis Tingkat Kelayakan Bahan Ajar Ekonomi yang Digunakan Oleh Guru di SMA Negeri 4 Jember. Jurnal Pendidikan Ekonomi, 9(2), 129-146. 
Patria Education Jurnal (PEJ) Vol 01 No.02 September 2021

Kusumam, A., Mukhidin, M., \& Hasan, B. (2016). Pengembangan Bahan Ajar Mata Pelajaran Dasar dan Pengukuran Listrik untuk Sekolah Menengah Kejuruan. Jurnal Pendidikan Teknologi dan Kejuruan, 23(1), 28. https://doi.org/10.21831/jptk.v23i1.9352

Novitasari. (2019). Pengembangan Modul Pembelajaran Pendidikan Jasmani, Olahraga Dan Kesehatan (Penjaskes) Melalui Pendekatan Jelajah Alam Sekitar Untuk Kelas Ii Sd/Mi. Journal of Chemical Information and Modeling, 53(9), 1689-1699.

Purwaningtyas, W. D. D., \& Hariyadi, I. (2017). Pengembangan Modul Elektronik Berbasis Online Dengan Program Edmodo. Jurnal Pendidikan, 2(1), 123, 121-129. journal.um.ac.id/index.php/jptpp/article/download/8471/4100

Qomara, Dwi, Y. (2019). Pengembangan Permainan Bola Besar Melalui Modifikasi Permainan Sepakbola Tangan. Jurnal Pendidikan Jasmani Kesehatan dan Rekreasi(Penjaskesrek), 6, 1-20.

Rahdiyanta, D. (2016). Teknik Penyusunan Modul Pembelajaran. Academia, 1-14.

Yusup, Febrianawati. 2018. Uji Validitas Dan Reliabilitas Instrumen Penelitian Kuantitatif. Jurnal Tarbiyah: Jurnal Ilmiah Kependidikan, (Online). 1(7): 17-23, (Http://Jurnal.Uintasari.Ac.Id/Index.Php/Jtjik/Article/View/2100), Diakses Tanggal 17 Desember 2020. 